\title{
Lenin and Pravda, 1912-1914
}

In 1962 a gathering of Soviet historians at the Academy of Sciences chose the fiftieth anniversary of Pravda's founding to call attention to certain shortcomings in Soviet scholarship concerning V. I. Lenin's leadership of the famous Bolshevik daily. It was noted that although a considerable amount had been written on Lenin's literary contributions to the paper, insufficient attention had been paid to the problem of its political leadership during the crucial two years before the war. ${ }^{1}$ This observation heralded the publication of several detailed studies which predictably found that Stalin, Molotov, and certain other "conciliatory elements" within Pravda's editorial board had hindered Lenin's efforts to complete the work of the Prague Conference in equating the Bolshevik faction with the Russian Social Democratic Labor Party. ${ }^{2}$ These studies minimized, however, the degree of his dissatisfaction with the paper and the hostility which his efforts to control Pravda engendered among its editors. Moreover, no Soviet historians and very few of their Western counterparts have questioned the basic assumptions that Lenin was instrumental in founding Pravda and that through it he stimulated and directed the growing unrest that characterized Russia's prewar industrial society. The reticence of Soviet historians to question the "Pravda legend" might be tunderstandable. But it is harder to explain why Western scholars have ignored the wealth of material found in Lenin's recently published correspondence and in the formerly suppressed resolutions of his Central Committee, which would indicate that the relations between the Bolshevik leader and his famous newspaper were anything but smooth and harmonious. ${ }^{3}$

1. "V otdelenii istoricheskikh nauk AN SSSR i nauchnykh sovetakh," Voprosy istorii, 1962 , no. 8, pp. 122-23.

2. See, for example, S. A. Andronov, Boevoe oruzhie partii: Gazeta 'Pravda' v 1912-1917 godakh (Leningrad, 1962) ; V. T. Loginov, Lenin i 'Pravda,' 1912-1914 godov (Moscow, 1962); and numerous journal articles cited below.

3. V. I. Lenin, Polnoe sobranie sochinenii, 5th ed., 55 vols. (Moscow, 1958-65), vol. 48, which includes fifty-two letters to the editors of Pravda, half of which did not appear in his "collected works" before 1957. "Deiatel'nost' TsK RSDRP po rukovodstvu gazetoi 'Pravda,' 1912-1914 gg.," Istoricheskii arkhiv, 1959, no. 4, pp. 39-56; "Zasedaniia TsK RSDRP 15-17 aprelia 1914 goda," Voprosy istorii KPSS, 1957, no. 4, pp. 112-25; G. V. Petriakov, "Deiatel'nost' V. I. Lenina po rukovodstvu 'Pravdoi' v 1912-1914 godakh,"

The author wishes to express his appreciation to the fellows of St. Antony's College, Oxford University, for assistance rendered during the preparation of this article. 
The basic reason for Lenin's difficulties with Pravda was that he in fact had very little to do with its creation and thus had little control over its initial operation. When the Mensheviks first broached the idea of establishing a legal workers' daily in late 1910, Lenin was unenthusiastic and uncooperative. He said that a legal newspaper would give the workers of Russia the impression that lasting political change could be obtained through legal, evolutionary means. Moreover, he felt that such a venture would be both expensive and impractical, owing to the restraints placed on newspapers by the tsarist press law. ${ }^{4}$ Unstated but fundamental in his decision was the realization that since at that time he did not control the organizational machinery of the party, it was highly unlikely that he could dominate a major undertaking such as the creation of a daily newspaper inside Russia.

The idea of a workers' newspaper evoked a warmer response among trade unionists and party members in St. Petersburg. Zvezda, the semiBolshevik weekly publication of the Social Democratic Duma fraction, estab- lished a commission in April 1911 to explore the matter and carried extensive correspondence regarding its feasibility. The consensus of this discussion was that a daily workers' newspaper was indeed needed to unite the scattered proletariat in the capital as well as to win back the worker-readers who, in the absence of other alternatives, bought cheap and readable but non-Social Democratic papers such as Gazeta kopeika and Sovremennoe slovo. Many workers stressed, however, that the proposed paper should be written by the workers themselves, unlike the abortive attempts at legal dailies during the 1905-7 period which were written by members of the intelligentsia either for their own consumption or in a condescending manner "for the workers." It was noted that in papers of the latter kind the editors avoided contentious or theoretical questions which they felt the workers either were not interested in or would not understand. At the same time, the proponents of a legal daily wanted to avoid the excessive attention given to factional politics by the illegal émigré newspapers which reached St. Petersburg irregularly and in small numbers from abroad. What was needed, according to the editors of Zvezda, was a cheap daily, run by the workers themselves, written in reasonably simple language, void of factional squabbling, but nevertheless taking a Social Democratic approach to all of the important issues facing the growing Russian proletariat: 5

Voprosy istorii, 1956, no. 11, pp. 3-16. Many of these resolutions, which were omitted from earlier volumes of collected party documents, have been included in the eighth edition of Kommunisticheskaia partiia sovetskogo soinza v rezoliutsiiakh i resheniiakh $s^{\prime \prime} e z d o v$, konferentsii i plenumov TsK (hereafter KPSS v rez.), vol. 1: 1898-1917 (Moscow, 1970).

4. Lenin, $P S S, 48: 33-34$.

5. These arguments are summarized by one of Zvesda's editors, N. N. Baturin, in Zvezda, no. 1, Jan. 6, 1912, p. 1; see also correspondence in Zvezda, no. 28, Nov. 5, 1911, pp. $1-2$; no. 33 , Dec. 10,1911 , p. 2 ; no. 35 , Dec. 22 , 1911, p. 5 ; no. 36 , Dec. 31 , 1911, p. 3 ; 
This sentiment was communicated to Lenin by St. Petersburg workers both at the Longjumeau party school during the summer of 1911 and at the Prague Party Conference in January 1912.6 At the latter gathering, some of the delegates criticized the existing illegal press and in their own name wrote to Maxim Gorky asking for financial and organizational assistance in "setting up in Russia a daily Social Democratic kopek newspaper."7 Although the conference did not pass a formal resolution on the question, it was approved in principle and received Lenin's qualified support. ${ }^{8}$ The Bolshevik leader reversed his earlier position for at least four reasons. First, as a result of the conference, he now controlled what purported to be the official machinery of the party in the form of a new, Bolshevik-dominated Central Committee and its Russian Bureau. Second, he was in the process of shifting his overall emphasis toward operating through so-called legal opportunities, as a result of the underground's lack of productivity and the concurrent easing up of the government's restrictions on legal trade unions, the open press, and so forth. Moreover, the most important of these legal opportunities was the State Duma; and the Bolsheviks, who had largely ignored the Third Duma, were determined to exploit the agitational potential of the forthcoming elections to the Fourth Duma. "Everyone realizes," Lenin later wrote in Pravda, "that without a [daily workers'] newspaper, participation in the elections would be virtually a sham. A newspaper is the chief weapon in the election campaign, the chief means for Marxist agitation among the masses."9 Finally, Lenin probably felt that a popular newspaper under his control would help to complete the work of the Prague Conference in expelling all the nonBolshevik elements from the RSDRP.10

Immediately after the Prague Conference, Lenin and two other members of his new Central Committee, S. S. Spandarian and R. V. Malinovsky, went

no. 2, Jan. 15, 1912, p. 3; and comments by M. S. Ol'minsky, in Pravda, no. 101, Aug. 26, 1912 , p. 3.

6. V. T. Loginov, "Lenin i 'Pravda," Bol'shevistskaia pechat' $i$ rabochii klass rossii $v$ gody revoliutsionnogo pod"ema, 1910-1914 (Moscow, 1965), pp. 49-50. p. 20 .

7. "O podgotovke prazhskoi konferentsii RSDRP," Istoricheskii arkhiv, 1958, no. 5,

8. A. K. Voronsky, The Waters of Life and Death (London, [1936]), p. 314; Lenin, PSS, 48:81. According to G. E. Zinoviev, however, a number of the émigré Bolsheviks at the conference still had serious reservations about the scheme. Pravda, no. 98, May 5, 1922, p. 1.

9. Lenin, PSS, $21: 453$.

10. Lenin might also have been motivated by a desire to counteract Menshevik plans for a joint or competing publication (Lenin, PSS, 48:37-38). Menshevik efforts in this direction during early 1912 were frustrated by a combination of a lack of money, inopportune arrests, and Bolshevik uncooperativeness now that they had stolen the march on their factional rivals. As a result, the Menshevik daily Luch did not appear until Sept. 16, 1912. See N. G. Poletaev, Pravda, no. 100, May 5, 1925, p. 3, and Pis'ma P. B. Aksel'roda i Iu. O. Martova, 1901-1916 (Berlin, 1924), pp. 223-26. 
to Leipzig where they met on January 19, 1912 (O.S.), with N. G. Poletaev and V. E. Shurkanov, who represented the Social Democratic group in the Third Duma. Poletaev, moreover, was the publisher of Zvezda and a leading exponent of a daily newspaper. The chief question under discussion, according to the police, ${ }^{11}$ was precisely the publication of a Bolshevik daily and more particularly the acquisition of the necessary financial support for such a venture. The proposal was once again approved in principle, and the Central Committee promised 1,000 rubles for its support and suggested that Zvezda turn to wealthy private individuals for the remainder.

After this moderately encouraging discussion, Poletaev returned to St. Petersburg to make the necessary preparations concerning the paper's editorial guidance, financing, and nomenclature. The first question was resolved in early February when a meeting of six or seven of Zvezda's leading contributors decided that they themselves would direct the future newspaper, perhaps in cooperation with some of the so-called Party Menshevik followers of George Plekhanov. ${ }^{12}$ The meeting also determined that 10,000 to 12,000 rubles would be needed to launch the new paper. It is part of the Pravda legend that this money was raised solely from among the Russian workers. In fact, however, the fund-raising campaign which Zvezda started in February collected only 3,858 rubles (or 30 percent of the total sum) from this source. ${ }^{13}$ The Central Committee, besides its initial 1,000 rubles, contributed an additional 3,000 rubles in two installments during March and early April.

For the remaining money Zvezda turned to wealthy sympathizers. Maxim Gorky, in response to the request of the Prague delegates, contributed 2,000 rubles but was pessimistic about finding further money from among his bourgeois acquaintances, who he felt "looked on such a publication only as a means of curbing worker socialists and of turning them into worker liberals" and would therefore present unacceptable conditions in return for their financial support. ${ }^{14}$ Poletaev did, however, find one other wealthy contributor. On March 20, 1912, he wrote the Central Committee that "the heir of a certain

11. M. A. Tsiavlovsky, ed., Bol'sheviki: Dokumenty po istorii bol'shevizma s 1903 po 1916 god byvsh. Moskovskago okhrannago otdeleniia (Moscow, 1918), pp. 102-3. Since both Malinovsky and Shurkanov were their agents, the police should have been well informed about this meeting.

12. Iz epokhi 'Zvezdy' $i$ 'Pravdy,' 1911-1914 gg., 3 vols. (Moscow, 1921-24), 3:232; G. Zinoviev, Histoire du parti comnuniste Russe (Paris, 1926), p. 156.

13. Zvezda, no. 33, Apr. 22, 1912, p. 4. Of this sum, 1,100 rubles came in four relatively large donations of more than 100 rubles each from individuals who probably could not be properly classified as "workers." Indeed, the published figures may have been purposely inflated and falsified to hide money derived from other, illicit sources mentioned below. Poletaev, in a letter written to the Central Committee on March 20, when Zvezda was publicly acknowledging receipt of 1,600 rubles, stated privately that worker contributions had brought in only 600 rubles. $I z$ epokhi 'Zvezdy' $i$ 'Pravdy,' $3: 236$.

14. Maksim Gor'ky, Sobranie sochinenii, 30 vols. (Moscow, 1949-55), 29:222-23. "Daty zhizni i deiatel'nosti A. M. Gor'kogo," Krasnyi arkhiv, 1936, no. 5, p. 76. 
factory owner" had promised 3,000 rubles for the venture. ${ }^{15}$ It is interesting to speculate whether this unnamed "heir" was V. A. Tikhomirnov. Tikhomirnov, the son of a successful Kazan merchant, had inherited some 300,000 rubles. He joined the Social Democratic Party in 1906, was arrested three years later, and in 1911 went abroad, where he saw Lenin before returning to St. Petersburg in 1912. According to one early Soviet source, "he gave his material support" for the founding of a daily Bolshevik newspaper, though the size and the recipient of this legacy are left unstated. ${ }^{10}$ Thus, although the paper was not "created exclusively by the workers' own means," as Pravda claimed"17 and Soviet historians assert, neither is there evidence that it was financed by the Okhrana, as Groza and other right-wing contemporary newspapers charged and some recent Western biographers maintain. ${ }^{18}$

On April 10, 1912, after having collected the stipulated 12,000 rubles, Poletaev received a permit to publish a daily newspaper called Pravda. The name was not his first choice. Originally the intention had been to transform Zvezda into a daily. Indeed, that paper increased its frequency to twice weekly on January 21 and to three times a week on March 8 . At the same time, its circulation climbed from 7,000 to around 30,000. This scheme, however, had two drawbacks. Zvezda was an old-style intelligentsia newspaper: its articles were long, abstract, and neither particularly comprehensible nor enjoyable for the new audience the editors hoped to attract. Second and more important, Zvezda had run afoul of the censor in January. The result was a court decision, confirmed by the Senate in April, that the paper had to be closed and the use of its name terminated. This left the émigré leaders in a quandary. Lenin, for a time, thought that the new paper would be called "Izvestiia," and Zinoviev was upset when he heard that the editors might expropriate the title of the Bolshevik's foreign journal, Rabochaia gazeta. ${ }^{19}$ Since any name chosen had to be approved by the Press Commission, other traditional titles of party

15. Iz epokhi 'Zvezdy' $i$ 'Pravdy,' $3: 236$.

16. See the biography of V. M. Molotov (who was active in the Kazan organization at the same time as Tikhomirnov) in Deiateli SSSR $i$ Oktiabr'skoi revoliutsii: Avtobiografii $i$ biografii (Moscow, 1926), 2:63. Additional information will be found in Iu. Denike, "Kupecheskaia sem'ia Tikhomirnovykh," Novyi Zhurnal, no. 68 (1962), pp. 28087; and in Bertram D. Wolfe, Three Who Made a Revolution: A Biographical History (New York, 1948), p. 559.

17. Pravda, no. 101, Aug. 26, 1912, p. 3.

18. See, for example, Stefan T. Possony, Lenin: The Compulsive Revolutionary (Chicago, 1964), p. 132; and Edward Ellis Smith, The Young Stalin: The Early Years of an Elusive Revolutionary (New York, 1967), p. 259. Police reports would indicate that the Okhrana was well aware of the potential danger of the proposed legal papers and did everything in its power to nip them in the bud, rather than financing their establishment (see reports in V. G. Kikoin, "'Zvezda' i 'Pravda,'” Krasnaia letopis, 1930, no. 2, pp. 67-109; and F. Drabkina, ed., "Tsarskoe pravitel'stvo i 'Pravda," Istoricheskii shurnal, 1937 , no. 3/4, pp. 115-23).

19. Lenin, PSS, 48:58; Iz epokhi 'Zvezdy' $i$ 'Pravdy,' $3: 182$. 
newspapers (Sotsial-demokrat, Proletarii) were discarded as unnecessary provocations. Still others were turned down because they were either already in use or were reserved for prospective publications. While perusing a list of approved titles, Poletaev noticed that an option to print a "religiousmoralistic" newspaper called Pravda had been granted to an official of the Holy Synod. Since the option had been allowed to lapse, Poletaev approached the official in question and received his permission to use the title to publish a daily paper of rather different orientation..$^{20}$ Poletaev, of course, was well aware that Leon Trotsky had been publishing a paper of the same name for the past four years in Vienna. The fact that Trotsky's Pravda, which was written in the workers' idiom and preached party unity, was quite clearly the most popular of the émigré papers reaching the Russian workers served as an added if unpremeditated inducement to publish a paper by this name.21

The first issue of the St. Petersburg Pravda appeared on April 22, 1912. It had four pages and cost two kopeks. ${ }^{22}$ On the first and second pages were five short articles, mostly concerning economic matters, and two proletarian poems. On the remaining two pages were the beginnings of special, and later very popular, feature sections- "Chronicle," "In the Workers' Movement," "Strikes in Progress," "Duma Affairs," and so forth-that were mostly contributed by the workers themselves. The masthead listed as editor one M. E. Egorov and the publisher, Poletaev. Egorov (like the forty-two other nonentities who followed him) was the responsible or "sitting" editor (sitzredakteur) whose sole function was to go to jail when necessary to save the party from paying a large fine or losing a valuable but unpublicized member of the editorial staff. ${ }^{23}$ The publisher, who was the legal owner of the paper and controller of its finances, had to be individually responsible if not journalistically competent. The party often chose its publishers from among the members of the Social Democratic Duma fraction, who had the additional advantage of having parliamentary immunity. Also listed on the masthead of

20. Istoriia 'Pravdy' $v$ datakh i chislakh, 1912-1927 (Leningrad, 1927), p. 7; G. V. Petriakov, Kollektivnyi agitator, propagandist $i$ organizator: Leninskaia 'Pravda' v 1912$1914 \mathrm{gg}$. (Moscow, 1967), p. 14.

21. Trotsky, who clearly thought that Poletaev had intentionally expropriated the name of his paper, accused the editors and Lenin of "plagiarism" and "usurpation" and called on them "officially" to change its name (Pravda [Vienna], no. 26, Apr. 23, 1912, p. 6; and letter to N. S. Chkheidze in Lenin o Trotskom i o trotskizna, Moscow, 1925, pp. 171-73). For Lenin's suggested reply, see Lenin, PSS, 48:69.

22. Pravda was published daily, except on Monday, and kept to the four-page format except on Christmas, New Year's, occasional Sundays, and such "red letter" days as Marx's birthday and International Women's Day, when it appeared in a six-page edition.

23. An interesting police account of the role of the responsible editor will be found in 'Zhandarmy o 'Pravde," "Proletarskaia revoliutsiia, 1923, no. 2, pp. 460-61. See also Whitman Bassow, "The Pre-Revolutionary Pravda and Tsarist Censorship," Anerican Slavic and East European Revicev, 13, no. 1 (February 1954): 47-65. 
the first issue of Pravda were its contributors, among them Gorky, ${ }^{24}$ Rosa Luxemburg, Plekhanov, ${ }^{25}$ Lenin (under his pseudonym "Il'in"), L. B. Kamenev, and G. E. Zinoviev. The masthead did not list, for obvious reasons, the Social Democratic secretary of the editorial board (at first F. F. Raskolnikov and after his arrest in May 1912, V. M. Molotov), who took care of the secret correspondence with the Central Committee abroad, or the actual editors who decided editorial policy and selected articles for publication. ${ }^{26}$

Pravda initially was a great success. During April and May between 40,000 and 60,000 copies of each issue were sold, and the editors even managed to make a profit of several hundred rubles on retail sales and a modest amount of beer, cigarette, and book advertising. ${ }^{27}$ Its appearance coincided with the sharp increase in worker unrest which followed the shooting of the Lena gold miners on April 4, 1912. During the month that followed, over a quarter million workers went out on strike. Pravda served to illuminate, reflect, and intensify this unrest. Even abroad the paper met with a favorable reception. Martov wrote Akselrod on May 16 that the new "Bolshevik daily Pravda has taken a very moderate tone and even spouts unity phrases."28

The one person who was strangely quiet about the appearance of Pravda was Lenin. The first issue contained neither his greetings nor an article from his pen. Indeed, no article by the Bolshevik leader appeared until the thirteenth issue (May 8, 1912), and then there was silence again until July 12-twelve weeks after the publication of the paper which he allegedly founded and led. This silence is especially surprising, since the editorial board requested his contributions on June 16 , noting the lack of publishable material, ${ }^{29}$ and since Lenin himself was a prolific and usually generous writer when it came to helping new ventures of a proper political perspective. In articles which Lenin published elsewhere during this time he did not mention the appearance of Pravda until July 1, 1912, when he wrote in Nevskaia zvezda (Zvezda's weekly stuccessor), "Only in Petersburg is there even a tolerably well-organized working class press, one which . . . is able to reflect, however faintly, the views

24. It is part of the Pravda legend that Gorky, the "first proletarian writer," contributed regularly to the party's first proletarian daily. Actually Gorky contributed only four stories (and two of these were initially written for other publications) despite constant entreaties for more by both Lenin and the editors.

25. Plekhanov, however, protested sharply that he had not given permission for his name to be listed as a contributor. G. V. Plekhanov, Sochineniia, 24 vols. (Moscow, 1923-27), 19:562-63.

26. Because of Soviet reticence on the subject, the exact composition of Pravda's editorial board during 1912 is difficult to determine. It probably included Poletaev, Baturin, Olminsky, S. M. Zaks-Gladnev, I. P. Pokrovsky, S. S. Danilov, and K. S. Eremeev.

27. Iz epokhi 'Zvezdy' $i$ 'Pravdy,' 3:245.

28. Pis'ma Aksel'roda i Martova, p. 231.

29. Sce Molotov's letter in "Novyi pod"em rabochego dvizheniia, 1910-1914," Krasnyi arkhiv, 1934, no. 1, p. 234. 
of the worker democrats." ${ }^{\prime 30} \mathrm{He}$ was no more enthusiastic in his private correspondence, wherein Pravda went unmentioned until July 11.

One of the reasons often given for Lenin's lack of participation was that he was involved in the time-consuming task of moving closer to Pravda's base of operations. Krupskaia recounted, "When the first issue of Pravda came out we began preparations to move to Cracow."31 Judging from Lenin's own correspondence, however, this move was neither planned before Pravda's appearance nor hastily executed after April 22. He wrote his mother on March 25, "We intend to go to Fontenay near Paris during the summer and are considering moving there for the year around." 32 On May 14 and again on May 20 he informed her that they still had no definite plans for the summer. The Lenins showed no real interest in moving closer to the Russian frontier until May 21, when Krupskaia inquired through V. A. Karpinsky about living conditions in Galicia. ${ }^{33}$ One month later-that is, two months after Pravda first appeared-Lenin finally took up residence in Galicia. One might note that Zinoviev, who also moved to Cracow, managed to publish at least thirty-one articles in Pravda during the time that Lenin wrote one. ${ }^{34}$

The real causes for Lenin's unexpected silence are to be found in the independent origins of Pravda and in his strained relations with its editors. Shortly after the Leipzig meeting with Poletaev, Lenin sent G. K. Ordzhonikidze (a Longjumeau graduate and recently elected member of the Central Committee) to St. Petersburg to oversee preparations for the daily newspaper. His reports were hardly encouraging. On February 10 he wrote Krupskaia that the Central Committee would be allowed to name only one of the three members of Pravda's editorial board and that Poletaev was "threatening to turn to our competitors" unless more money was sent immediately. ${ }^{35}$ Shortly thereafter Ordzhonikidze was forced to leave St. Petersburg and was arrested before the paper appeared. Lenin was left in the lurch. He wrote to Poletaev in mid-March, "Write precisely about when the daily paper [will be published], its format, and so forth."36 He tried again on April 9: "Let us know immediately concerning the daily newspaper. What will be its format? What length articles can be sent?"37

In desperation he turned to three of his protégés in the Russian Bureau of the Central Committee: "Nothing from Ivanovich. What is he doing? Where

30. Lenin, PSS, $21: 375$ (italics added).

31. N. K. Krupskaia, Vospominaniia o Lenine (Moscow, 1957), p. 187.

32. Lenin, PSS, 55:323.

33. Cited in Petriakov, Kollektivnyi agitator, p. 26.

34. See M. S. Ol'minsky and M. A. Savel'ev, eds., Pravda, vols. 1-3 (Moscow, 1933), wherein the editors attempted to identify the pseudonyms of authors of reprinted articles.

35. Iz epokhi 'Zvezdy' i 'Pravdy,' 3:232.

36. Lenin, PSS, 48:52.

37. Ibid., p. 62 . 
is he? How is he getting on? It is absolutely necessary to have someone legally in Petersburg. ... We have neither information, nor guidance, nor supervision of the newspaper."38 "Ivanovich" was, of course, one of the pseudonyms of I. V. Stalin, who had been co-opted to the Central Committee shortly after the Prague Conference while still in exile. He had been visited by Ordzhonikidze in February and apparently had been given instructions to replace his visitor as the Central Committee's man in St. Petersburg. ${ }^{39}$ Stalin escaped from Solvychegodsk on February 29, but for unexplained reasons did not show up in the capital until April 10. By that time the preparatory work for publishing Pravda had been completed. ${ }^{40}$ During the next twelve days he wrote eight articles for Zvezda and almost single-handedly edited three issues of that paper, thus freeing its regular editors for more important work in bringing out the new daily. On April 22, the day that Pravda finally appeared, Stalin was arrested.

Not only was Lenin uninvolved in and uninformed about the actual preparation of "his" newspaper, but he also experienced a cooling off of relations with its organizers. During the spring of 1912 the editors of Zvezda, in addition to delivering ultimatums concerning Pravda's financing, also exercised their discretion in editing several of his articles intended for their newspaper. In mid-March Lenin wrote that they "should abstain and keep quiet" when it came to altering his election platform for publication.41 Poletaev's rather condescending reply ${ }^{42}$ did not please him, and on April 9 the Bolshevik leader threatened to break off all relations if he was not allowed to defend the Prague Conference in Zvezda against Plekhanov's attacks on it. ${ }^{43}$

The final straw probably came when Lenin saw the first issue of Pravda itself. The conciliatory tone which Martov had noted ${ }^{44}$ was readily evident in Stalin's lead article entitled "Our Aims":

38. Ibid., pp. $53-54$.

39. See Ordzhonikidze's letter of February 24 to the Central Committee in Is epokhi 'Zvezdy' $i$ 'Pravdy,' 3:233.

40. Stalin himself claimed to the contrary. In 1922 he wrote, "One evening in the middle of April 1912, in the apartment of comrade Poletaev, two Duma deputies (Pokrovsky and Poletaev), two writers (Olminsky and Baturin), and I (a member of the Central Committee) ... agreed on the platform of Pravda and drew up the first issue." I. V. Stalin, Sochineniia, 13 vols. (Moscow, 1947-53), 5:130. This statement became the basis of the Pravda legend that the paper was "founded on the instructions of V. I. Lenin by the initiative of I. V. Stalin" (ibid., 2:389).

41. Lenin, PSS, 48:52.

42. Iz epokhi 'Zvezdy' $i$ 'Pravdy', 3:235-39.

43. Lenin, $P S S, 48: 61$.

44. Martov was quite correct when he informed P. A. Garvi, "The tone taken by Pravda undoubtedly testifies to the fact that Lenin has almost no one to serve as his 'conscience' in Russia." He speculated that Zinoviev would soon be sent to replace Ordzhonikidze and Stalin. Pis'ma Aksel'roda i Martova, p. 235. 
In pursuing these aims, we by no means intend to gloss over differences that exist among Social Democratic workers . . . , "complete identity of views" can only exist in the graveyard. But this does not mean that points of disagreement will be more significant than points of agreement. ... Pravda will call, first and foremost, for unity in the proletarian class struggle, for unity at all costs. . . Peace and cooperation within the movement-that is what Pravda will be guided by in its daily work.

If this policy were implemented, it would mean a reversal of the decisions taken at the Prague Conference. Rather than narrowing the definition of Social Democrat still further, the editors of Pravda apparently were seeking to reunify the party against Lenin's wishes.

During the summer of 1912, after having settled in Galicia and with the Duma elections rapidly approaching, Lenin finally began to take an active interest in writing for Pravda. His relations with the newspaper during the last six months of 1912, however, were anything but cordial. A whole series of minor irritants developed. He complained, for example, that the editors were slow in sending him his honorarium of 100 rubles a month which he was entitled to as "a permanent political contributor." ${ }^{45} \mathrm{He}$ was upset that Pravda arrived in the afternoon mail rather than in the morning delivery with the bourgeois papers. "Clearly the dispatch department is functioning carelessly," he chided the editors. ${ }^{46}$ Lenin also complained that the editorial board was reluctant to send him the books he needed for writing his articles, and suggested that someone in the St. Petersburg office was removing material intended for him. "We repeat that it is impossible to work without books," he reminded the editors. ${ }^{4 \tau}$ This problem was compounded by the fact that he "knew only five words of Polish" and thus was unable to use the rich resources of Cracow's libraries.8

More serious problems also developed with Pravda. It soon became evident that the editors in St. Petersburg were altering Lenin's articles to remove the abrasive terms which he habitually used when referring to his factional opponents. Lenin complained on July 19, 1912, "Why does Pravda persistently and systematically strike out any mention of the Liquidators both from my

45. Lenin, PSS, 48:66, 116, 191, and 207. Lenin's salary, which was considerably higher than that paid the actual editors in St. Petersburg (see financial report in "Deiatel'nost' TsK," pp. 44-45), provided him with his first regular source of income. His conscience must have bothered him, for he wrote Gorky, "There is nothing wrong about contributors to a workers' paper receiving regular payment; to the contrary, this is all to the good. ... What is bad about everyone working for a workers' paper beginning to earn a little? What is offensive about this proposal? (PSS, 48:100).

46. Lenin, PSS, 48:164; see also pp. 208 and 213.

47. Ibid., p. 68 (Lenin's emphasis).

48. See letters to his mother and sister, ibid., 55:339, 347, and 444. 
articles and from those of other colleagues ?"49 The editors' stated policy of avoiding pejorative terms such as "Liquidator" and of ignoring "painful" factional questions which they felt would be of little interest to the average Pravda reader ${ }^{50}$ was modified somewhat in August when Lenin was allowed to refer to "so-called Liquidators." "51 One of the editors, M. S. Olminsky, informed him on August 27: "The paper, as you can see, has broken its silence concerning the Liquidators. ... [However,] strong language and sharpness go too far: the tone should be mocking or regretful condescension [toward the Mensheviks] while explaining the facts to the public." He concluded by cautioning Lenin, "The form of your article should not be polemical." 52 These explanations and minor concessions obviously did not please the Bolshevik leader. As Krupskaia remembered, "Vladimir Ilich was very upset when Pravda at first removed all polemics with the Liquidators from his articles. $\mathrm{He}$ wrote angry letters to Pravda [protesting about this]."53

"But worse things than this happened," continued Krupskaia. "Sometimes, although rarely, Ilich's articles were lost. Sometimes they were held up or printed only after considerable delay. Ilich grew nervous and wrote angry letters to Pravda, but they did not do much good." emphasize that Pravda printed more than 284 of Lenin's articles. What they do not mention, and what Krupskaia was reticent to acknowledge, is that the editors also rejected many of his articles. A close reading of Lenin's correspondence with the editorial board and of his subsequently printed manuscripts would indicate that he wrote forty-seven articles between March 1912 and July 1914 that the editors in St. Petersburg chose not to publish. Lenin expressed the sentiment of many aspiring writers when he wrote his editors: "Why did you kill my article on the Italian Congress? In general, it would do no harm to inform [authors] about rejected articles. This is by no means an excessive request. To write 'for the wastebasket,' that is, articles to be thrown out, is not very enjoyable. Unpublished articles should be returned. Any contributor, even to bourgeois newspapers, would demand this."55 Olminsky later acknowledged that Pravda did indeed reject articles of numerous prestigious émigrés. He noted that some were unaccustomed to writing for legal publications and thus produced manuscripts that clearly could never get past the

49. Ibid., $48: 78$.

50. Cited in Zinoviev's letter to the editors of July 8, 1912, in Iz cpokhi ' $Z v e z d y$ ' $i$ 'Pravdy,' 3:188-89.

51. Pravda, no. 80 , Aug. 1,1912 , p. 1. This qualification does not appear in articles Lenin published in journals under his own editorship.

52. Iz epokhi 'Zvezdy' $i$ 'Pravdy,' 3:243.

53. Krupskaia, Vospominaniia o Lenine, p. 194.

54. Ibid., p. 210.

55. Lenin, PSS, 48:74 (Lenin's emphasis). This article did in fact appear somewhat later in Pravda, no. 66, July 15, 1912, p. 1. 
censor. ${ }^{56}$ Other articles-and many of Lenin's probably fall into this category -were considered too factional in content and not "popular" enough in tone for Pravda's readership. ${ }^{57}$ Still others were "killed" because they were too intellectual in tone. For this reason one émigré, who sent in fifteen articles, received thirteen rejection slips, and another was told that "phrases in French, German, and Spanish" were inappropriate in a proletarian newspaper. ${ }^{58}$

One consequence of having to please conciliatory editors and suspicious censors was that Lenin wrote on numerous safe but exceedingly dull topics. It is hard to imagine the average worker receiving much edification or stimulation from his accounts on margarine consumption in Western Europe, or "On the Development of Worker Choirs in Germany" (rejected by the editors), or on the implications of Switzerland's changing from a nation of innkeepers to a nation of proletarians as industrialization was introduced in the Alps. Later he even tried his hand at yellow journalism when he discussed the rape of an eleven-year-old Indian girl by a British colonel who was subsequently acquitted by a British judge. ${ }^{59}$

The raison d'être for Pravda, at least in Lenin's mind, had been the Duma election campaign. He therefore was very upset when the editors failed to exploit the agitational potential of the campaign sufficiently or espoused election alliances contrary to those approved by the Prague Conference. $\mathrm{He}$ wrote the editors in late September, "The undersigned, now in the capacity of a permanent political contributor to Pravda and Nevskaia zvezda, considers it his duty to protest against the conduct of his colleagues in charge of these papers at this crucial time." "Pravda," he said, "conducts itself now, at election time, like a sleepy old maid. Pravda doesn't know how to fight. It neither attacks nor goes after either the Kadets or the Liquidators. . . Pravda is 'serious,' affectatious, and totally uncombative!! Is this really Marxism?"60

All these petty annoyances and more substantial complaints led Lenin to the conclusion that Pravda's editors sought to take advantage of their somewhat independent creation and their geographic isolation to create an autonomous position for themselves vis-à-vis the Central Committee. This was reenforced by the board's apparent lack of respect. He complained at one point, "I have received a stupid and insolent letter from the editorial board [which] I shall not answer." ${ }^{.61}$ On another occasion he must have been less than happy

56. Iz epokhi 'Zvezdy' $i$ 'Pravdy,' 1:44.

57. On occasion, some of these were published in Nevskaia zvezda, much to the displeasure of Lenin who wanted the larger Pravda audience. See Lenin, PSS, 48:73.

58. Iz epokhi 'Zvezdy' $i$ 'Pravdy,' $1: 44$. It is quite possible that a number of these articles were written by Kamenev, who, to Lenin's irritation, had his first eight manuscripts rejected by Pravda's editors. See ibid., 3:189; and Lenin, PSS, 48:70 and 87.

59. Ibid., $21: 397-99$ and $466-68,22: 275-76,23: 89-90$.

60. Ibid., 48:97-98, 95.

61. Ibid., p. 152. 
to be told by Molotov, Pravda's twenty-two-year-old secretary, that the editors in St. Petersburg knew better than the Central Committee in Galicia what the Russian workers wanted to read, and that too many articles from his pen attacking the Kadets made for "monotonous reading." 62 Soviet historians have since claimed that the retirement of Poletaev and I. P. Pokrovsky from active participation in Pravda after the termination of the Third Duma in June, as well as the arrest of N. N. Baturin in November, left the paper in the hands of the "autonomists"-Olminsky, S. S. Danilov, S. M. Zaks-Gladnev, S. M. Nakhimson, N. N. Lebedev-the majority of whom desired to be conciliatory toward the other Social Democratic factions and autonomous from the central institutions of their own faction. ${ }^{63}$

The incorrectness of this approach seemed evident to Lenin in the paper's falling circulation and revenue. From a circulation of 60,000 in the spring of 1912 Pravda fell to 20,000 in the summer. Instead of making a profit the paper was now losing 1,500 rubles a month. Collections, which had come from 396 worker groups in the second quarter of 1912, were received from only 81 groups in the third quarter, and from 35 groups in the fourth quarter. ${ }^{64}$ As a result Pravda was in a difficult financial position by the end of the year. As Lenin wrote to Gorky in December, "The paper is in trouble: since the summer decline in circulation, the rise has been very slow and a deficit remains." "If we cannot find cash to expand and strengthen Pravda, it will perish."65

Lenin tried a number of ways to solve these problems during the last half of 1912 , but none of them proved satisfactory. He wrote many of those "angry letters" which Krupskaia remembered, in an attempt to force the editors to accept his point of view. On July 11 he informed them:

I have received your long letter and see that we most certainly must have it out. . . You complain about monotony. But this will always be the case if you don't carry polemics, if . . you reduce everything to "positive liquidationism." Moreover, you will drive away all of your contributors if you don't print them, don't even answer [their letters], and don't send back their articles (for example, mine). . . . By avoiding "painful questions," Pravda and Zvezda make themselves dry, monotonous, uninteresting, uncombative organs. A socialist organ must conduct polemics. ${ }^{60}$

A little later he wrote to Pravda: "You will spoil everything and provoke

62. Iz epokhi 'Zvezdy' $i$ 'Pravdy,' $3: 240$. It is perhaps as a result of this correspondence that Lenin developed a rather negative view of Molotov, whom he later allegedly referred to as an "incurable dumbbell" and a "glorified filing clerk."

63. See, for example, Loginov, Bol'shevistskaia pechat', p. 56.

64. Statistics on Pravda's circulation and income can be found in Lenin, PSS, 23: 97-98, 48:133; Iz epokhi 'Zvezdy' i 'Pravdy,' 3:245.

65. Lenin, PSS, 48:137 and 139 (Lenin's emphasis). See also letters to Kamenev, 48:121, 143, and 145 .

66. Ibid., pp. 70-71 (Lenin's emphasis). 
protests from the workers on the left, if you keep silent about this. The Liquidators must be rebuffed. . . . If you don't want to spoil and aggravate everything 'on the left,' publish this 'Reply to the Liquidators." "67 The "Reply" typically went unpublished. Lenin also suggested, with an equal lack of success, that the editors come to Galicia to discuss their mutual differences. ${ }^{68}$

When these efforts failed, he tried to use the good offices of personal representatives in St. Petersburg to bring about editorial changes. Inessa Armand, after a short stay in Cracow, was sent to the Russian capital to negotiate with the editors through the local party organization. Soviet historians claim to see some improvement after these talks took place in August, but they point to nothing specific. Shortly before Inessa Armand's arrest on September 14 Stalin arrived back in St. Petersburg with the commission, according to A. E. Badaev, of running Pravda, organizing the last stage of the election campaign, and setting up the Bolshevik portion of the Duma fraction. ${ }^{69}$ During the fall and early winter Stalin did in fact write five articles for Pravda and made three trips to Galicia to confer with Lenin on newspaper tactics. As will be seen, these endeavors had little effect. Finally, it might be noted that Lenin tried to recruit Demian Bedny, the author of forgettable revolutionary lyrics, as an inside informant on editorial board personalities and policies. ${ }^{70}$ Bedny had appeared on the list of Pravda's original contributors and had published "useful propagandistic doggerel" in numerous issues during 1912. Later in the year, because of his rather eccentric personal behavior or some political indiscretion, he had a falling out with the editors. Lenin, however, continued to champion his cause with the board, and at the same time sought useful information from his new protégé. Judging from Bedny's letters, it is doubtful whether he was a better spy than he was a poet. ${ }^{71}$

Despairing of a negotiated settlement, Lenin tried to impose changes on the editorial board in October. After a meeting of the Central Committee in Galicia, it was decided that henceforth there would be two "troikas"-one for editorial matters and the other for business affairs-both responsible to the Central Committee. ${ }^{72}$ Since it was felt "from past experience that local forces [were] unable to provide the necessary leadership,"73 Stalin, as the Central Committee's illegal resident in St. Petersburg, was told to implement this deci-

67. Ibid., 21:395-96 (Lenin's emphasis).

68. Ibid., $48: 72$ and 76; Iz epokhi 'Zvezdy' $i$ 'Pravdy, 3:244.

69. A. Badayev, The Bolsheviks in the Tsarist Duma (London, n.d.), p. 25.

70. Lenin, PSS, 48:117.

71. See Peter Reddaway, "Literature, the Arts and the Personality of Lenin," in Lenin: The Man, the Theorist, the Leader (London, 1967), pp. 49-50.

72. V. T. Loginov, "O rukovodstve TsK RSDRP bol'shevistskoi gazetoi 'Pravda' v 1912-1914 gg.," Voprosy istorii KPSS, 1957, no. 1, p. 121.

73. Iz cpokhi 'Zvezdy' i 'Pravdy,' 3:201. 
sion. Krupskaia wrote to him that "everything sent to 'V' [Pravda] should be seen by you and without your approval nothing should be done." ${ }^{\prime 4}$ On November 1 Molotov informed Lenin of the results: "Inside the editorial board, as you probably know, some changes have been made in the direction you clesired. In general there have been no radical alterations-there has been a replenishment of the board and perhaps a more correct distribution of editorial functions." ${ }^{\prime \prime 5}$ This was not enough, as events during December were to demonstrate.

The first blow came when Pravda's rather inactive publisher was suspected of embezzlement. In what was probably nothing more than a case of lax financial accounting, Malinovsky sowed seeds of suspicion when he informed Lenin that "it smacks of a criminal act," the Panama Canal scandal of the 1880 s. He went on to say that the resulting financial difficulties forced the board to suspend payment of Lenin's honorarium. The Bolshevik leader angrily replied that this would compel him and the Central Committee to leave Cracow. ${ }^{77}$ "For God's sake," he wrote Stalin, "take the most energetic steps to get ' $W$ ' [Pravda] away from 'Krass' [Poletaev] and put it formally in [Duma deputy M. K.] Muranov's name; in particular, take over the funds and the subscription money. Without these we are lost."78

One crisis led to another in December. On December 11 Pravda included in its list of contributors the name of Lenin's philosophical and factional bete noire, A. A. Bogdanov, who had been expelled from the Bolshevik ranks three and a half years earlier. Shortly thereafter some of his articles began to appear in Pravda. Lenin, who was "staggered" to learn about this only from the newspaper itself, wrote Gorky that Bogdanov's articles were "the same old Machism-idealism concealed in such a way that . . the stupid editors of Pravda could not understand" them. ${ }^{79}$ Matters came to a head on December 15 when eleven of the thirteen Social Democratic members of the Fourth Duma voted to merge the Menshevik Luch with the Bolshevik Pravda. While this was being arranged, the Menshevik and Bolshevik deputies (with the exception of Malinovsky and Muranov) agreed to contribute to each other's papers,

74. Ibid., p. 203.

75. Ibid., p. 245.

76. Quoted in Lenin, PSS, $48: 126$ and 129.

77. See letter to Stalin of Dec. 10, 1912, in Iz epokhi 'Zvezdy' $i$ 'Pravdy' 3:201-2. Although this letter is attributed to Krupskaia and is not found in Lenin's collected works, it is obviously of his authorship. 129-30).

78. Lenin, PSS, 48:127. See also his letter to the Duma fraction of Dec. 4, 1912 (pp.

79. Ibid., p. 161 ; see also Krupskaia's letter to Stalin of Dec. 14, 1912, in Iz epokhi 'Zvesdy' $i$ 'Pravdy,' 3:203. Ironically, Bogdanov protested that his name had been listed among Pravda's contributors without his permission and should be removed. Pravda, no. 24, Jan. 30, 1913, p. 2. 
and on December 18 Pravda duly listed the seven Menshevik deputies among its contributors. This, to Lenin, was the outcome of the conciliatory attitude taken by Pravda from its very first issue. It threatened still further to undermine the work of the Prague Conference, and could lead to the loss of the organizational advantages gained a year earlier. Accordingly, he called the Duma deputies and a few available party workers to Cracow for a decisive meeting with the Central Committee.

The fact that the Cracow or "February" Meeting, as it was called for conspiratorial reasons, even considered the Pravda crisis was ignored by Soviet historians until 1956. It is difficult to say whether this was because of a lack of documentation, ${ }^{80}$ or because candid discussion would have contradicted the Pravda legend, or because the meeting implicitly criticized Stalin's handling of the paper during the preceding fall. In any case, the resolution passed by a closed meeting of the Central Committee on January 1, 1913, sharply attacked the editorial board for being "insufficiently firm in its party spirit" and for "responding weakly to the party life of the Petersburg Social Democratic workers." It instructed the editors to "devote more attention to explaining the incorrectness and harmfulness of liquidationism," and noted that "steps were being taken to reorganize the editorial board." 81

This time the reorganization was entrusted to Iakov Sverdlov (who was co-opted to the Central Committee and named de facto editor) rather than to Stalin. Perhaps realizing that the plans for a joint newspaper ${ }^{82}$ had more local support than Lenin would admit, Sverdlov was forced to seek allies among the Duma deputies and editorial workers as well as negotiate with his opponents before trying to impose the Cracow settlement on Pravda. During the resulting delay the paper's old editors committed still more errors from Lenin's point of view. This brought forth a spate of angry letters from Cracow. Lenin wrote the Bolshevik Duma deputies on January 12, 1913, "The absence of news about the plan to reorganize the editorial board is extremely disturbing. What is going on? . . Reorganization, or better yet the complete expulsion of all the old-timers, is absolutely essential." 83 On January 27 he reiterated the problem in even stronger terms to Sverdlov:

80. Considerable material concerning Central Committee activities in Galicia, which Lenin had to abandon when World War I broke out, was turned over to the Soviet Union only in 1954.

81. KPSS v res., $1: 367$.

82. It is difficult to piece together information about this abortive venture. It apparently had a name (Rabochii golos), a coalitional editorial board under Poletaev, and a treasury of several thousand rubles. It collapsed when the Bolshevik Duma deputies fell into line behind Lenin. See letters from Zinoviev ("Lenin i 'Pravda,' 1912-1913 gg.: Perepiska," Krasnaia letopis, 1924, no. 1, pp. 72-73) and from Stalin (Iz epokhi 'Zvezdy' $i$ 'Pravdy,' 3:246-47).

83. Lenin, PSS, 48:152. 
The key to the present situation is precisely $D e n^{\prime}[$ Pravda] and its management. Unless we secure reform and proper management here, we shall be bankrupt both financially and politically. . . . Things are bad in Petersburg primarily because $D e n^{\prime}$ is bad. ... It is essential to insert our own editorial board and to throw out the present one. . . Would you call these people editors? They are not men but miserable milksops and wreckers of the cause. ... You must put an end to the so-called "autonomy" of these good-for-nothing editors. You must do this before all else. Stay put in a "sanctuary" with No. 1 [Duma deputy Badaev]. Install a telephone. Take the editorial board into your own hands. Draw in assistants. You on your own-with some of these people as mere functionaries -given our work from here, can fully cope with the job. ${ }^{84}$

Lenin did not yet know that five days earlier, in the room of Duma deputy G. I. Petrovsky, a meeting of twelve Bolsheviks had taken place at which the reorganization had finally been effected. Sverdlov had been confirmed as editor in chief with veto powers; Badaev had been confirmed as publisher replacing Poletaev; K. N. Samoilova had replaced Molotov as secretary; two three-man boards had been established-one for editorial matters under Petrovsky and the other for business affairs under Badaev. Most of the earlier editors were quietly given other, less crucial, assignments where their skills could be used but their opinions ignored. ${ }^{85}$ Lenin was overjoyed on February 6 when he heard the results of Sverdlov's meeting: "We learned today about the beginning of the reform in $D e n^{\prime}$. A thousand greetings, congratulations, and best wishes for success. At last you have managed to begin the reform. You cannot imagine how tired we are of working with a sullenly hostile editorial board." 86 Four days later, however, Sverdlov was arrested, and on February 23 Stalin, who had returned to the capital a week earlier, was also picked up, at a benefit concert for Pravda, on the basis of information provided the police by Malinovsky.

84. Ibid., pp. 156-58 (Lenin's emphasis). See also letters from Zinoviev and Krupskaia in $I z$ epokhi 'Zvezdy' $i$ 'Pravdy,' 3:203-10.

85. See police report in "K 20-letiiu smerti Y. M. Sverdlova," Krasnyi arkhiv, 1939, no. 1, p. 80. Trotsky concluded (Stalin: An Appraisal of the Man and His Influence, New York, 1941, pp. 146-51) that Stalin was also in momentary disgrace, because he was sent to Vienna to work on the nationality problem rather than back to St. Petersburg. Although it is evident that he had been unsuccessful in bringing Pravda under the Central Committee's thumb and had probably contributed to its conciliatory trend (see, for example, his article on E. O. Jagiello in Pravda, no. 182, Dec. 1, 1912), it should be noted that none of Lenin's letters to him during this period imply dissatisfaction (see letters of Nov. 23 and 28, Dec. 1 and 3, in Lenin, PSS, 48:117-29; and one sent in Krupskaia's name on December 10 in Iz epokhi 'Zvezdy' $i$ 'Pravdy,' 3:201-2). It might be argued that it was consistent with Stalin's character that he leaned one direction in St. Petersburg and another in Cracow and thus escaped censure from either side.

86. Lenin, PSS, 48:163. 
Just before his arrest Stalin had written the Central Committee that the next de facto editor of Pravda should be a legal resident of St. Petersburg who could take an active part in the paper's daily work, rather than an illegal operative (such as himself or Sverdlov) who had to stay in hiding much of the time. He suggested that S. G. Shaumian, an Armenian Social Democrat and a candidate member of the Central Committee, be considered for this post. ${ }^{87}$ Shaumian came to St. Petersburg but refused the job when he found that certain editorial changes he wanted would not be made. The party also approached I. I. Skvortsov-Stepanov, who, like Shaumian, was an experienced Bolshevik just released from detention, but he also found reasons to avoid accepting a position that was likely to bring down upon him the wrath of Lenin and the Okhrana alike. ${ }^{88}$ Thus, because of the arrest or the reluctance of experienced and trusted party publicists, editorial responsibility by default was left to the Bolshevik deputies in the Fourth Duma and especially to Petrovsky. As Krupskaia remembered, these were "honest and reliable proletarians," ${ }^{89}$ but they were untrained and perhaps unable to edit a large daily newspaper under trying conditions. Lenin acknowledged to Kamenev, "There is a general complaint that we lack the men. The Liquidators have intelligentsia by the score while all ours get arrested." ${ }^{90} \mathrm{He}$ continued in the same vein to Gorky in September: "I have heard that you are dissatisfied with Pravda. Because of its dryness? You are right. But it is not easy to correct this shortcoming all at once. We haven't the personnel. With great difficulty, one year after it was established, we have secured a merely tolerable editorial board."

To develop the resources he had available, Lenin began planning another party school, this time especially for the Duma deputies so that he might improve their political and journalistic competence..$^{22}$ His personal contributions to Pravda also increased: during May and June of 1913 fifty of his articles, longer and more polemical than before, appeared on its pages. He regularly discussed with the editors plans to publish a Sunday supplement (which he

87. Iz epokhi 'Zvesdy' $i$ 'Pravdy,' $3: 246$. This letter is mistakenly attributed to Sverdlov.

88. A. M. Volodarskaia, Lenin $i$ partiia v gody nazrevaniia revolintsionnogo krizisa, 1913-1914 (Moscow, 1960), pp. 126-27; Petriakov, Voprosy istorii, 1956, no. 11, p. 9. The choice of Skvortsov-Stepanov is curious, because Lenin at the time had a very negative view of his political and journalistic abilities. See letter to Gorky in Lenin, PSS, 48: 153-54.

89. Krupskaia, Vospominaniia o Lenine, p. 197.

90. Lenin, $P S S, 48: 172$.

91. Ibid., p. 211 (Lenin's emphasis).

92. See letters to Gorky, Plekhanov, and Kamenev, ibid., pp. 139, 198-99, 201-2. The school, which was to have met at Lenin's summer home in Poronin, never was held owing to a lack of money, the arrest of the school's organizer, and the reluctance of some of the deputies to leave Russia during the Duma recess. Volodarskaia, Lenin i partiia, pp. 144, $154-61$. 
hoped would attract 100,000 new readers) as well as the technicalities of increasing Pravda's format now that circulation had once again risen to $32,000 .^{93}$ There were occasional rough periods during the spring and early summer of 1913, such as the time Lenin threatened to resign because Pravda printed Bogdanov's rejoinder to him under the heading "A Factual Explanation," but generally he took a milder tone and seemed to assume that mistakes were the result of inexperience rather than of a purposely conciliatory or autonomous policy as before. Thus he wrote the editors on June 3 that they had "clearly made a mistake on the question of the seven-hour day for postal employees. We all make mistakes; there is nothing particularly wrong in this." 95 Of far more concern to Lenin at this time was the sickness of his wife, and on June 10 they left for Switzerland so that she might have an operation.

During Lenin's six-week absence a new problem developed within Pravda which required his hasty return for a meeting with Zinoviev and Malinovsky on July 27 . Malinovsky, according to a police report which he himself probably filed, told of a strange meeting he had had with the new editor of Pravda, Miron Chernomazov. Chernomazov had for several years been active in the publishing of the party's central organ, Sotsial-demokrat, in Paris. In May he had returned to Russia to assume the editorship of Pravda and had promptly been arrested. Upon being released from custody, he told Malinovsky that "five days after his arrest [he had been] invited to the Okhrana where, during questioning, they began to suggest that he take on the duty of being a secret informer for the investigatory body. The interrogator said that though the Okhrana 'knew all,' they wanted to obtain information 'firsthand' with the help of Chernomazov. In an effort to persuade him to take on [this] role... the interrogator proceeded to demonstrate the Okhrana's thorough knowledge of recent party developments." The meeting concluded that "all these circumstances merely confirmed the fact that near to the 'six' [Bolshevik Duma deputies] there was a person tied to the investigatory branch of the government." 90

In all likelihood Chernomazov did indeed become an Okhrana agent as a result of his arrest, perhaps under the inducement of a monthly salary of 200 rubles. ${ }^{97}$ Nevertheless, it is difficult to accept the frequently stated conclusion

93. Lenin, PSS, 48:174, 182-83, 188-89; and letter from the Central Committee to N. I. Podvoisky in "1912-1913 gg.," Proletarskaia revoliutsiia, 1923, no. 2, pp. 442-43.

94. Pravda, no. 120, May 26, 1913, p. 2; Lenin, PSS, 23:246-47.

95. Lenin, PSS, 48:189.

96. Tsiavlovsky, Bol'sheviki, p. 131.

97. Ibid., p. xxii. Soviet historians have tried to minimize Chernomazov's role in Pravda's operations by claiming that he was merely the secretary of its editorial board. Some Western writers (e.g., Possony and Smith), on the other hand, have tried to magnify 
that Malinovsky told this story to shift suspicion from himself to Chernomazov. Few people suspected Malinovsky as early as July 1913, and, more to the point, Chernomazov was retained in his new position for another six months, during which time he did immense harm to the paper and to Social Democracy. More than likely Malinovsky was merely trying to prove his own value to the party and at the same time find out how much Lenin and Zinoviev suspected about police infiltration of their ranks.

The government's crackdown on Pravda coincided with Chernomazov's editorship but was the result, the Central Committee felt, of pressure by the Council of United Nobility, which saw the workers' press as primarily responsible for the resurgence of factory unrest. ${ }^{98}$ On July 5, 1913, Pravda was closed "in view of its distinctly party character."99 One week later it reappeared as Rabochaia pravda with a new responsible editor and a new publisher (police agent Shurkanov) but with the same editorial board headed by Chernomazov. Rabochaia pravda lasted only seventeen issues, then it too was closed by order of the Press Commission. In the succeeding five months three more versions of Pravda were suppressed. Moreover, the rate of daily confiscation increased so that during the July to September period 80 percent of the issues were seized for displeasing the censor. As a result of the newspaper's irregular appearance the circulation in the autumn of 1913 fell to 18,000 , and by the end of the year there was a deficit of 3,000 rubles..$^{100}$

Lenin reacted to these events by preaching legality to Chernomazov and by considering other means of party agitation. "It seems to me," he wrote Chernomazov in September, "that you are making a gigantic mistake in drifting unconsciously with the current and in not changing the tone of the paper. Everything indicates that both the tone and the content must be changed. . . . It is necessary to strive for legality, to be able to pass the censor. This can and must be achieved. Otherwise you are destroying, for no purpose at all, the work you have undertaken." ${ }^{101} \mathrm{He}$ also criticized the editor for writing articles on topics, such as the party's autumn conference in Poronin and the connection between the various Pravdas, which justified suppression of the paper. ${ }^{102}$ At

his role by claiming that he was the "official editor" from the paper's very inception. In reality, while Chernomazov had no association with Pravda before May 1913, after that date he was its de facto editor.

98. See police report of Aug. 15, 1913, in "Novyi pod"em," p. 242.

99. See court decision in Kikoin, Krasnaia letopis, 1930, no. 2, p. 106.

100. Ibid., p. 105; Loginov, Bol'shevistskaia pechat", p. 66; "Deiatel'nost' TsK," p. 53.

101. Lenin, $P S S, 48: 212$ (Lenin's emphasis).

102. Ibid., pp. 214 and 260. Judging from Lenin's correspondence, he did not suspect that these were deliberate provocations. See, for instance, the very friendly and complimentary letter which he and Kamenev sent to Chernomazov on Oct. 8, 1913, in Krasnaia letopis, 1924, no. 1, pp. 78-79. Lenin's portion of this letter is not reproduced in his Polnoe sobranie sochinenii. 
the same time, Lenin asked the editors, "Why publish a daily? I don't understand. I advise changing over to a weekly paper." 103 With this in mind he revived plans for the increased publication of illegal newspapers abroad and of underground literature in Russia. ${ }^{104}$

During the winter of 1913 the problem of Chernomazov's editorship came to a head over the question of his dictatorial methods. Colleagues informed the Central Committee that he refused to circulate contentious articles, that he printed his own articles under the heading "From the Editors," that he insisted on receiving Lenin's correspondence unopened, and that he treated his fellow editors rudely. ${ }^{105}$ On November 13 A. A. Troianovsky replied from Cracow that although these complaints seemed justified, it would be "awkward" to act on them immediately. He therefore suggested that the Russian Bureau of the Central Committee should merely investigate the matter more thoroughly. ${ }^{106}$ During the first three weeks of December Chernomazov was out of town, perhaps on vacation. In his absence the paper was run by M. A. Saveliev, and to the Central Committee's pleasure, ${ }^{107}$ the rate of confiscation dropped drastically. On December 27 a special meeting of the Central Committee was called in Cracow to consider the Pravda problem once again. The job of "strengthening Pravda," whose position had been "severely shaken," was considered the "most urgent and important task" facing the party. The members of the Duma fraction were instructed to "concentrate their efforts on strengthening Pravda even if work in the Duma should temporarily suffer." They were told to watch over the paper's legality, to improve its business operations, and to increase its circulation. Pravda's editors were told that their work must be "strictly collective"; that the paper must become more varied by including belles-lettres, poetry, satire, and history; and that locally written articles or those of a polemical nature had to be sent abroad for approval if any member of the editorial board or the Duma fraction deemed it necessary. ${ }^{108}$

More direct steps to limit Chernomazov's influence were being taken in St. Petersburg. Elena Rozmirovich, who served as Pravda's secretary at the time, wrote to Cracow in mid-January 1914 that the old problems still remained. The complete "reform of Pravda is necessary," she said. "But to do all that we planned is impossible. First of all, the absence of Malinovsky [he was in Western Europe with Lenin] hinders our work. . . . I have undertaken

103. Lenin, PSS, 48:207.

104. Ibid., p. 200; Tsiavlovsky, Bol'sheviki, pp. 132-33; KPSS v rez., 1:384.

105. See letters from K. N. Samoilova and E. F. Rozmirovich in "Deiatel'nost' TsK," pp. 45-48.

106. "Iz perepiski TsK RSDRP s mestnymi partiinymi organizatsiiami, 1912-1914 gg.," Istoricheskii arkhiv, 1960, no. 2, p. 30.

107. "Deiatel'nost' TsK," p. 42.

108. Ibid., pp. 41-43. 
to mobilize the necessary people so that we can act resolutely when Malinovsky returns." 100 The decisive factor was not Malinovsky's return but rather evidence presented by Olminsky in early February that Chernomazov was indeed tied to the Okhrana. Since the evidence was considered inconclusive, his colleagues merely transferred him from the editorial board to the job of managing Pravda's warehouse. Several days later, however, the Bolshevik Duma fraction voted to remove him from all party posts. ${ }^{110}$

To pick up the pieces after Chernomazov's removal, Lenin sent his number three man and one of the party's most experienced publicists, L. B. Kamenev, to St. Petersburg to take over Pravda. Under Kamenev's leadership, which lasted until the war, Pravda achieved its greatest success since the spring of 1912 and its most harmonious relations with its Galician overseer. Lenin wrote to Inessa Armand in early March 1914: "How much better looking Pravda has become under Brother [Kamenev]-it's getting to be a real beauty! It is pleasant just to look at it. For the first time, one can see the leadership of a cultured and knowledgeable local editor."111 And to Kamenev he sent "a thousand greetings to the paper-which has become a thousand times better."112 Lenin was particularly pleased with the special supplements for miners and for workers of particular regions as well as features on insurance matters and agrarian problems which his new editor introduced. Under Kamenev the financial position of the paper also improved. The number of permanent subscribers doubled, and the average daily circulation climbed back to 40,000 copies, even reaching 130,000 on Pravda's second anniversary. In honor of the occasion a commemorative double issue was published and a special fund-raising drive was started which ultimately brought in more than 18,000 rubles. ${ }^{113}$

Pravda's literary and financial improvement during the spring of 1914 hardly made it "the most popular paper in the country," as one recent Soviet historian has claimed. ${ }^{114}$ Nevertheless, the paper had acquired a national audience, being distributed to some 944 cities in Imperial Russia. ${ }^{115}$ Its

109. Ibid., p. 46.

110. See letters from Rozmirovich (Feb. 5, 1914) and Samoilova (Feb. 9, 1914) to the Central Committee, ibid., pp. 50-52. Lenin's account of Chernomazov's dismissal, written in 1917, differs somewhat in detail from the above summary. See Lenin, PSS, 31: 79-82.

111. Ibid., 48:272 (Lenin's emphasis).

112. Ibid., p. 279.

113. Ibid., $25: 420$.

114. I. A. Portiankin, "V. I. Lenin i bol'shevistskaia pechat', 1895-1914 godov," Voprosy istorii, 1961, no. 4, p. 20.

115. B. N. Ponomarev, ed., Istoriia kommnntisticheskoi partii sovetskogo soiusa, 3rd ed. (Moscow, 1969), p. 147. 
columns about workers' problems and interests undoubtedly gave a sense of class identity and solidarity to its readers. Its accounts of economic abuses and of successful strikes helped spread social and economic unrest. By constantly harping on the correctness of the six Bolshevik Duma deputies and championing Bolshevik candidates in trade union and insurance elections, it promoted factional identification which had been conspicuously absent before 1912 . Pravda, for all its difficulties, provided a degree of political coordination and leadership that had been lacking since 1905.116

Aside from a strike by typographical workers in February 1914, which forced Pravda to suspend publication for eleven days, ${ }^{117}$ the Bolsheviks faced only two new crises during the six months before the war. The first was Roman Malinovsky's sudden and suspicious resignation as a Bolshevik Duma deputy in May. Lenin's reaction to Malinovsky's apparent betrayal of the party was to hush up the matter and attack the Mensheviks for spreading "malicious rumors" about his being an agent provocateur. "Stop being nervous," he wrote Petrovsky. "[There] is no need to expel him [from the party]." "Why discuss the matter? Why waste the time?"118 $\mathrm{He}$ instructed Kamenev to defend Malinovsky and to accuse his detractors of disrupting the party. The editorial board, however, probably realizing the truth in the accusations before Lenin, toned down its defense, withheld publication of Lenin's more vitriolic attacks on the Mensheviks, ${ }^{119}$ and dismissed Pravda's publisher, one S. A. Malinovskaia, on May 17. Malinovsky's subsequent exoneration by a hand-picked tribunal in Galicia was published in Pravda without editorial comment. After the Malinovsky affair had been swept under the rug, almost all of Lenin's attention was devoted to the second crisis-the "Unity Conference" convened by the International Socialist Bureau in Brussels during early

116. See police report of June 30, 1914, in Proletarskaia revolittsiia, 1923, no. 2, p. 456.

117. Put' pravdy, no. 15, Feb. 18, 1914, p. 1; and letter from Samoilova to the Central Committee in "Deiatel'nost' TsK," p. 51. The Bolsheviks' only consolation was that the strike, which Samoilova acknowledged "came at a very inopportune moment," also closed papers of the Mensheviks, the Socialist Revolutionaries, and the Black Hundreds-all of which were printed by the same press.

118. Lenin, PSS, 48:294. Malinovsky had far less connection with Pravda than is often assumed. During the formative stages of the paper he was absorbed in the Duma election campaign in Moscow. After the January 1913 reshuffle of the editorial board he was indeed given some responsibilities in the business side of the paper's operation, though it is unlikely that he served as its "treasurer" (Wolfe, Three Who Made a Revolution, pp. 478 and 548), and he certainly never was its publisher (Possony, Lenin, p. 131). During the summer of 1913 his attention was devoted solely to the new legal daily (Nash put $t^{\prime}$ ) that the party was trying to establish in Moscow, and in September 1913 the Central Committee removed him from all participation in Pravda affairs. V. I. Lenin, Sochineniia, 3rd ed. (Moscow, 1929), 17:736.

119. Lenin, PSS, 25:631. It is ironic that the one defense of Malinovsky by Lenin that the newspaper did publish ("Konets klevete," Rabochii, no. 4, May 25, 1914, p. 1) has been omitted from his Polnoc sobranie sochinenii. 
July. The Bolshevik leader refused to attend personally, but sent detailed instructions to Inessa Armand on how she should defend his faction before the Bureau. The conference's resolution, which implicitly condemned the schismatic activities of the Bolsheviks and advocated one more attempt at party unity, was passed by an overwhelming majority and represented another apparent defeat for Lenin.

Many Western historians have come to the conclusion on the basis of the Malinovsky affair, the defeat of the Bolsheviks in Brussels, and Lenin's alienation of almost all of the Russian and European Social Democratic leaders, that the Bolshevik leader "overplayed his hand" in the two and a half years between the Prague Conference and the outbreak of the war. ${ }^{120}$ Lenin, though he did not deny the strength of the émigre forces arrayed against him, put his emphasis on the Bolshevik preponderance in Russia. He stressed with some justification the Bolshevik victories in the Duma elections from the workers' curia, their take-over of the majority of the trade union directorates and insurance councils in the capitals, the greater financial support given by the workers to Pravda than to Luch, and the vastly larger circulation of Pravda during the second quarter of $1914 .{ }^{121}$ As a result of two and a half years' work, the majority of the Social Democratic workers in Russia now apparently identified themselves as Pravdaists. It seemed to Lenin that the work of the Prague Conference in equating the Bolshevik faction with the Russian Social Democratic Labor Party was finally nearing completion and needed only to be formalized at the forthcoming Sixth Party Congress scheduled to convene in Galicia during August 1914. Even his opponents recognized the gains of Bolshevism in Russia as the war approached. ${ }^{122}$

At the same time, worker unrest in Russia in the form of economic and political strikes was once again reaching the level of 1905. The Bolsheviks, through Pravda, reflected this growing militancy and unrest. Their victories in the trade unions and the insurance councils during 1914 indicated that the frustrated urban workers were responding to their extreme appeals rather than to the more moderate approach of the Mensheviks. It is arguable, however, whether the Bolsheviks caused this unrest or whether they could control its manifestations. Although the various "legal opportunities"- -such as the daily

120. See, for example, Leonard Schapiro, The Connnunist Party of the Soviet Union (New York, 1960), pp. 125-40.

121. Lenin summarized these facts in his written report to the Brussels Conference. Lenin, PSS, 25:371-77.

122. See, for example, letter of Apr. 10, 1914, from Potresov to Akselrod in A. N. Potresov and B. I. Nikolaevsky, eds., Sotsial-demokraticheskoe dvizhenie $v$ Rossii: Materialy, vol. 1 (Moscow, 1928), p. 270; and letter of Sept. 15, 1913, from Martov to Potresov quoted in Leopold Haimson, "The Problem of Social Stability in Urban Russia, 1905-1917," Slavic Revicw, 23, no. 4 (December 1964): 632. 
press, the Duma, trade unions, and insurance councils—had revived, the underground structure of the party was still largely dormant and rife with provocateurs. The illegal Russian Bureau of the Central Committee was virtually extinct; the publication of underground leaflets increased only marginally; and the longevity of the few conspiratorial city committees was decidedly limited. Moreover, as Lenin recognized, the Bolsheviks were not nearly as successful in the provinces as they were in St. Petersburg. ${ }^{123}$ Not only were the Mensheviks still strong in southern and central Russia, but worker unrest in those areas was not on a level with that in the capital. ${ }^{24}$

These inherent weaknesses in the Bolshevik position were all too evident during the July Days. No sooner had the demonstrations and strikes in St. Petersburg reached a decisive stage than Pravda was closed down by the police on July 8,1914 . Lenin, with his attention still focused on Brussels, was forced to seek information on what was happening in St. Petersburg through friends in Berlin. ${ }^{125}$ The Petersburg Committee, which should have provided coordination and guidance, reacted hesitantly and in a contradictory fashion to the insurrection at hand. When leadership was called for, they were unable to provide it or the workers failed to follow their suggestions. This failure of the party to provide adequate underground leadership in St. Petersburg, together with the failure of the Social Democratic and workers' organizations outside the capital to support the strikers in sufficient numbers to divert the government's repressive machinery, doomed the July Days and allowed the tsar to restore order five days before the war began. ${ }^{126}$

The epilogue to Lenin's troubled relations with Pravda before the war was played out in March 1917. One week after the formation of the Petrograd Soviet of Workers' Deputies, Pravda once again appeared under the direction of several of its leading prewar managers: Molotov, Olminsky, and Eremeev. N. N. Sukhanov called it "the confused organ of some very dubious politicians and writers," and said, "Its rabid articles and appeals to unruly instincts had neither definite objective nor clear purpose. It had no 'line' at all-merely a pogromist form." 127 The only "line" it did have during its first ten days was close to the one that Lenin had adopted independently in Switzerland. Pravda

123. Lenin, PSS, 25:234.

124. From information supplied by the factory inspectors it is evident that the Ukraine, for example, which employed about a fifth of the total Russian industrial labor force before the war, accounted for 27 percent of all Russian strikers in 1910, but only 14 percent in 1911, 9 percent in 1913, and 7 percent in the first half of 1914.

125. Lenin, PSS, 48:322.

126. For an excellent description of these events in St. Petersburg, see Haimson, "Problem of Social Stability," pp. 640-42.

127. N. Sukhanov, Zapiski o revoliutsii, vol. 2 (Berlin, 1922), p. 242. 
attacked cooperation with the Provisional Government, any form of defensive war, and any faith in the Menshevik leaders of the Petrograd Soviet.

On March 12, however, three higher ranking Pravdaists returned from Siberia, and on March 15 it was announced in the newspaper: "Member of the Central Organ of the party, comrade I. Kamenev, and member of the Central Committee of the party, comrade $\mathrm{K}$. Stalin, having arrived from exile, have joined the editorial board of Pravda, the general leadership of which has been taken over by the workers' deputy to the State Duma, comrade Muranov." It was to no avail that the leading Bolshevik in Petrograd, A. G. Shliapnikov, attacked this action as an "editorial coup d'état" and threatened to take it before the next party conference. ${ }^{128}$

Under the leadership of Kamenev and Stalin, Pravda's line toward the war and the Provisional Government moderated. Kamenev advocated a policy of "pressuring" the government for reform and of continuing a revolutionary defensive war. ${ }^{129}$ Stalin, at the party's March Conference, suggested that unity with the mainstream of Menshevism was desirable. ${ }^{130}$ Lenin's manuscripts sent to Pravda were once again consigned to the "wastebasket." The only article of his published before his return in April, the first "Letter from Afar," was cut by 20 percent in order to remove his hostile remarks concerning the moderate leaders of the Soviet and the policies that they were following. ${ }^{131}$ It is no wonder that when Kamenev boarded Lenin's train as it was approaching the Finland Station, the Bolshevik leader greeted him by asking, "What is this that is being written in Pravda? We saw several numbers and really gave you hell!"132 In the context of his relations with Pravda before the war, this was not the first time that he swore at the paper he supposedly founded and directed.

128. A. G. Shliapnikov, Semıadtsatyi god, vol. 2 (Moscow, 1925), p. 180 ; "Protokoly i rezoliutsii Biuro TsK RSDRP(b), mart 1917 g.," Voprosy istorii KPSS, 1962, no. 3, p. 150.

129. Pravda, no. 9, Mar. 15, 1917, p. 2.

130. "Protokoly vserossiiskogo (martovskogo) soveshchaniia partiinykh rabotnikov," Voprosy istorii KPSS, 1962, no. 6, p. 139.

131. For a textual comparison of Lenin's original manuscript with the published Pravda version, see A. V. Snegov, "Neskol'ko stranits iz istorii partii, mart-nachalo aprelia 1917 g.," Voprosy istorii KPSS, 1963, no. 2, pp. 22-24.

132. Quoted in F. F. Raskolnikov, "Priezd tov. Lenina v Rossiiu," Proletarskaia revolintsiia, 1923, no. 1, p. 221. 